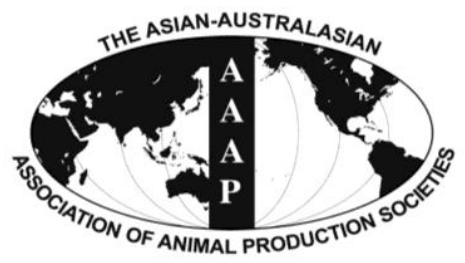

Asian Australas. J. Anim. Sci.

Vol. 26, No. 12 : 1689-1697 December 2013

http://dx.doi.org/10.5713/ajas.2013.13190

www.ajas.info

pISSN 1011-2367 elSSN 1976-5517

\title{
Effects of Physical Form and Urea Treatment of Rice Straw on Rumen Fermentation, Microbial Protein Synthesis and Nutrient Digestibility in Dairy Steers
}

\author{
P. Gunun, M. Wanapat*, and N. Anantasook \\ Tropical Feed Resources Research and Development Center (TROFREC), Department of Animal Science, \\ Faculty of Agriculture, Khon Kaen University, Khon Kaen 40002, Thailand
}

\begin{abstract}
This study was designed to determine the effect of physical form and urea treatment of rice straw on rumen fermentation, microbial protein synthesis and nutrient digestibility. Four rumen-fistulated dairy steers were randomly assigned according to a 2 ( 2 factorial arrangement in a 4 (4 Latin square design to receive four dietary treatments. Factor A was roughage source: untreated rice straw (RS) and urea-treated (3\%) rice straw (UTRS), and factor B was type of physical form of rice straw: long form rice straw $(\mathrm{LFR})$ and chopped $(4 \mathrm{~cm})$ rice straw $(\mathrm{CHR})$. The steers were offered the concentrate at $0.5 \%$ body weight $(\mathrm{BW}) / \mathrm{d}$ and rice straw was fed ad libitum. DM intake and nutrient digestibility were increased $(\mathrm{p}<0.05)$ by urea treatment. Ruminal $\mathrm{pH}$ were decreased $(\mathrm{p}<0.05)$ in UTRS fed group, while ruminal ammonia nitrogen $\left(\mathrm{NH}_{3}-\mathrm{N}\right)$ and blood urea nitrogen $(\mathrm{BUN})$ were increased $(\mathrm{p}<0.01)$ by urea treatment. Total volatile fatty acid (VFA) concentrations increased $(\mathrm{p}<0.01)$ when steers were fed UTRS. Furthermore, VFA concentrations were not altered by treatments $(p>0.05)$, except propionic acid $(C 3)$ was increased $(p<0.05)$ in UTRS fed group. Nitrogen $(N)$ balance was affected by urea treatment $(\mathrm{p}<0.05)$. Microbial protein synthesis (MCP) synthesis were greater by UTRS and CHR group ( $<<0.05)$. The efficiency of microbial $\mathrm{N}$ synthesis was greater for UTRS than for RS ( $\mathrm{p}<0.05)$. From these results, it can be concluded that using the long form combined with urea treatment of rice straw improved feed intake, digestibility, rumen fermentation and efficiency of microbial N synthesis in crossbred dairy steers. (Key Words: Rice Straw, Urea Treatment, Physical Forms, Rumen Fermentation, Microbial Protein Synthesis, Dairy Steers)
\end{abstract}

\section{INTRODUCTION}

In the tropics, most ruminants are fed on low-quality roughages, agricultural crop-residues and industrial byproducts (Wanapat, 2000; Wanapat et al., 2012). Rice straw is one of the major sources of roughages for ruminants in the tropics (Wanapat et al., 2009; Khandaker et al., 2012; Su et al., 2012). However, it is characterized by low levels of $\mathrm{CP}$ and high level of structural polysaccharides, which drastically affected the DM intake, digestion and ultimate performance (Wanapat et al., 1985; Chemjon, 1991; Safari et al., 2011). Improving the utilization of low quality roughages could be by treatment with nitrogen sources, chemical and physical treatment (McDonald et al., 2002; Nguyen et al., 2012). Urea treatment of rice straw could increase its nutritive value (Sundstøl et al., 1978; Abate and

\footnotetext{
* Corresponding Author: M. Wanapat. Tel: +66-43-202368, Fax: +66-43-202368, E-mail: metha@kku.ac.th

Submitted Apr. 7, 2013; Accepted Jun. 14, 2013; Revised Jul. 15, 2013
}

Melaku, 2009). Hart and Wanapat (1992) indicated that urea (5\%) treated rice straw improved overall intake, nutrient digestibility, VFA production and increased passage rate of particles in the rumen. Urea treatment may be the most suitable method for small-scale farmers improve the quality of straws (Hanafi et al., 2012). However, urea price is increasing and impacts on the high cost of roughage. Therefore, reducing levels of urea could be used as an alternative to 5\% urea for treatment as studied by Khejornsart and Wanapat (2010) who reported that treating rice straw with $3 \%$ urea could maintain the nutritive value, especially those of $\mathrm{NH}_{3}-\mathrm{N}$, total VFA and propionate concentration when compared with 5\% UTRS in vitro.

Particle size of roughage can impact on maintenance of rumen function, which has been associated with fiber digestibility and optimal $\mathrm{pH}$ for cellulolytic microorganisms (Beauchemin and Yang, 2005; Yang and Beauchemin, 2009; Maulfair et al., 2010). Zhao et al. (2009) reported that in goats fed rice straw increasing the particle size $(1,2,4$, and 
$8 \mathrm{~cm}$ ) resulted in increased chewing activity and enhanced ruminal function. In addition, Yang et al. (2002) also reported that increased forage particle size in dairy cow diets improved ruminal $\mathrm{pH}$ and MCP synthesis in the rumen with no effect on feed intake. On the other hand, decreasing roughage particle size increased VFA production particularly propionic acid and higher feed efficiency due to enhanced MCP synthesis (Kononoff and Heinrichs, 2003; Krause and Combs, 2003). However, limited data has been available regarding chopping and urea treatment of rice straw on the rumen fermentation, nutrient digestibility and MCP synthesis of steers. Therefore, the objective of this experiment was to investigate the effect of the physical form and urea treatment of rice straw on rumen fermentation, MCP synthesis and nutrient digestibility in crossbred dairy steers.

\section{MATERIALS AND METHODS}

\section{Animals, treatments and experimental design}

Four, rumen-fistulated Holstein-Friesian (HF) crossbred dairy steers (75\% HF and $25 \%$ Thai native breed) with an initial BW of 228 (16 kg were randomly assigned according to four dietary treatments according to a 2 (2 factorial arrangement in a 4 (4 Latin square design. Factor A was roughage source: untreated rice straw (RS) and urea-treated (3\%) rice straw (UTRS), factor B was type of physical forms of rice straw: long form rice straw (LFR) and chopped $(4 \mathrm{~cm})$ rice straw $(\mathrm{CHR})$. The concentrate was fed at the level of $0.5 \% \mathrm{BW} / \mathrm{d}$ with roughage was fed ad libitum. Chemical composition of concentrate, rice straw and ureatreated rice straw is presented in Table 1. Steers were housed individually and fed the experimental diets twice daily approximately at $0800 \mathrm{~h}$ and $1600 \mathrm{~h}$. Clean fresh water and mineral blocks were available ad libitum. The experiment was conducted for four periods, each period lasting for $21 \mathrm{~d}$, the first $14 \mathrm{~d}$ for feed intake measurements and the remaining $7 \mathrm{~d}$ for total urine and fecal collection, while the animals were housed in metabolism crates. Rice straw was chopped to a theoretical cut length $4 \mathrm{~cm}$ by machine. Urea-treated rice straw was prepared by using 3 $\mathrm{kg}$ urea of fertilizer grade $(46 \% \mathrm{~N})$ plus $100 \mathrm{~kg}$ water, sprayed onto $100 \mathrm{~kg}$ of rice straw and then covered up for $10 \mathrm{~d}$ before directly feeding to the animals (Wanapat et al., 2009).

\section{Data collection and sampling procedures}

The feed was sampled, fecal and urine samples were collected by total collected from each individual steer during the last $7 \mathrm{~d}$ of each period. Feeds, refusals and fecal samples were dried at 60 (C and ground ( $1 \mathrm{~mm}$ screen using Cyclotech Mill, Tecator) and analyzed using the standard methods of AOAC (1995) for DM, N and ash. Neutral
Table 1. Ingredients and chemical composition of concentrate, untreated rice straw and urea-treated $(3 \%)$ rice straw

\begin{tabular}{|c|c|c|c|}
\hline Item & Concentrate & $\mathrm{RS}^{1}$ & $\mathrm{UTRS}^{2}$ \\
\hline Ingredient & \multicolumn{3}{|c|}{ - $\%$ of DM } \\
\hline Cassava chip & 65.3 & - & - \\
\hline Coconut meal & 8.8 & - & - \\
\hline Palm kernel meal & 6.8 & - & - \\
\hline Rice bran & 9.5 & - & - \\
\hline Urea & 3.1 & - & - \\
\hline Molasses & 2.0 & - & - \\
\hline Tallow & 1.5 & - & - \\
\hline Salt & 1.0 & - & - \\
\hline Sulfur & 1.0 & - & - \\
\hline Mineral premix ${ }^{3}$ & 1.0 & - & - \\
\hline \multicolumn{4}{|l|}{ Chemical composition } \\
\hline Dry matter $(\mathrm{g} / \mathrm{kg})$ & 87.5 & 93.7 & 51.0 \\
\hline Organic matter & 92.4 & $\begin{array}{l}6 \text { of D } \\
86.7\end{array}$ & 85.0 \\
\hline Crude protein & 14.1 & 2.5 & 5.4 \\
\hline Neutral detergent fiber & 29.3 & 75.5 & 77.4 \\
\hline Acid detergent fiber & 19.4 & 55.2 & 54.6 \\
\hline Ash & 7.6 & 13.3 & 14.5 \\
\hline $\begin{array}{l}{ }^{1} \text { Untreated rice straw. } \\
{ }^{2} \text { Urea-treated (3\%) rice straw } \\
{ }^{3} \text { Minerals and vitamins (eac } \\
\text { Vitamin E, 70,000 IU; Vitan } \\
40 \mathrm{~g} ; \mathrm{Co}, 0.1 \mathrm{~g} ; \mathrm{Cu}, 10 \mathrm{~g} \text {; Se }\end{array}$ & $\begin{array}{l}\text { contains): } \\
1,600,000 \mathrm{I} \\
\mathrm{g} ; \mathrm{I}, 0.5 \mathrm{~g} .\end{array}$ & $\mathrm{A}$, & $\begin{array}{l}0,000 \mathrm{IU} \\
40 \mathrm{~g} ; \mathrm{Mn}\end{array}$ \\
\hline
\end{tabular}

detergent fiber (NDF) and acid detergent fiber (ADF) were analyzed according to Van Soest et al. (1991).

At the end of each period, rumen fluid was collected at 0 , 2,4 , and $6 \mathrm{~h}$ after the morning feeding through the rumen fistula. Approximate $200 \mathrm{~mL}$ of rumen fluid was collected at each time from the middle part of the rumen using a 60 $\mathrm{mL}$ hand syringe. Temperature and $\mathrm{pH}$ of rumen fluid were measured immediately using a portable $\mathrm{pH}$ and temperature meter (Hanna Instruments HI 8424 microcomputer, Singapore). Rumen fluid samples were then filtered through 4 layers of cheesecloth. Samples were used for $\mathrm{NH}_{3}-\mathrm{N}$ and VFA analysis to which $5 \mathrm{~mL}$ of $1 M$ sulfuric acid $\left(\mathrm{H}_{2} \mathrm{SO}_{4}\right)$ were added to $50 \mathrm{~mL}$ of rumen fluid. The mixture was centrifuged at $16,000 \times g$ for $15 \mathrm{~min}$. and the supernatant was stored at $-20^{\circ} \mathrm{C}$ before $\mathrm{NH}_{3}-\mathrm{N}$ analysis using Kjeltech Auto 1030 Analyzer and VFA were analyzed using highperformance liquid chromatography (HPLC) as described by Samuel et al. (1997).

At the same time as rumen fluid sampling, a blood sample (about $10 \mathrm{~mL}$ ) was collected from the jugular vein into tubes containing $12 \mathrm{mg}$ of EDTA and the plasma was separated by centrifugation at $500 \times \mathrm{g}$ for $10 \mathrm{~min}$ at $4^{\circ} \mathrm{C}$ and stored at $-20^{\circ} \mathrm{C}$ until analysis of BUN according to Crocker (1967). Urinary samples were analyzed for total $\mathrm{N}$ determined according to AOAC (1995) and allantoin determined by HPLC as described by Chen and Gomes 
(1995). The amount of microbial purines absorbed was calculated from purine derivative (PD) excretion based on the relationship derived by Chen and Gomes (1995). MCP $(\mathrm{g} / \mathrm{d})=3.99 \times 0.856 \times$ mmoles of purine derivatives excreted (Galo et al., 2003). The efficiency of microbial N synthesis (EMNS) was calculated using the following formula: EMNS = microbial $\mathrm{N}(\mathrm{g} / \mathrm{d}) / \mathrm{DOMR}$; where $\mathrm{DOMR}=$ digestible $\mathrm{OM}$ apparently fermented in the rumen (assuming that rumen digestion was $65 \%$ of digestion in total tract, $\mathrm{DOMR}=\mathrm{DOMI} \times 0.65 ;$ DOMI $=$ digestible organic matter intake).

\section{Statistical analysis}

All data were analyzed as a $2 \times 2$ factorial arrangement within a $4 \times 4$ Latin square design using the general linear procedure in PROC GLM of SAS (1996). The statistical model included terms for animal, period, roughage source, physical form, and interaction between roughage source and physical form. Comparison among treatments was tested by orthogonal contrast. Differences among means with $\mathrm{p}<0.05$ were accepted as statistically significant differences.

\section{RESULTS}

\section{Feed intake, nutrients intake and apparent digestibility}

The effect of physical form and urea treatment of rice straw on voluntary feed intake, nutrients intake and apparent digestibility in dairy steers are presented in Table 2. Rice straw intake, in terms of $\mathrm{kg} / \mathrm{d}$ and gram per metabolic body weight $\left(\mathrm{g} / \mathrm{kg} \mathrm{BW}^{0.75}\right)$, was increased by urea treatment $(\mathrm{p}<0.01$ and $\mathrm{p}<0.05$, respectively). Therefore, total DM intake was subsequently improved (from 4.7 to $5.7 \mathrm{~kg} / \mathrm{d}$ ) $(p<0.05)$. However, physical form did not significantly affect voluntary feed intake (rice straw intake and total intake) ( $>0.05)$. The nutrient intake and apparent digestibility in dairy steers receiving UTRS were increased when compared with RS $(\mathrm{p}<0.05)$, while steers receiving different physical form of rice straw were similar among treatments $(\mathrm{p}>0.05)$

\section{Characteristics of ruminal fermentation and blood metabolites}

The effect of physical form and urea treatment of rice straw on rumen fermentation and concentration of BUN are presented in Table 3. Ruminal pH was affected in the UTRS fed group. It was also affected by the roughage source and physical form interaction, with the lowest ruminal $\mathrm{pH}$ found in the UTRS+CHR $(\mathrm{p}<0.05)$ (Figure 1). Concentration of $\mathrm{NH}_{3}-\mathrm{N}$ and BUN was significantly affected by urea treatment $(\mathrm{p}<0.01)$ (Figures 2 and 3 , respectively). In addition, total VFA concentration was higher $(p<0.01)$ for UTRS than for RS. Molar proportion of acetic acid (C2), butyric acid $(\mathrm{C} 4)$ and $\mathrm{C} 2$ :C3 was not affected, whereas that of propionic acid increased in the UTRS fed group $(\mathrm{p}<0.05)$.

Table 2. Effect of physical form and urea treatment of rice straw on feed intake, nutrient intake and apparent nutrient digestibility of dairy steers

\begin{tabular}{|c|c|c|c|c|c|c|c|c|}
\hline \multirow{2}{*}{ Item } & \multicolumn{2}{|c|}{$\mathrm{RS}$} & \multicolumn{2}{|c|}{ UTRS } & \multirow{2}{*}{ SEM } & \multicolumn{3}{|c|}{ Significance $^{1}$} \\
\hline & LFR & CHR & LFR & CHR & & $\mathrm{U}$ & $\mathrm{P}$ & $\mathrm{U} \times \mathrm{P}$ \\
\hline \multicolumn{9}{|l|}{ DM intake } \\
\hline \multicolumn{9}{|l|}{ Rice straw } \\
\hline $\mathrm{kg} / \mathrm{d}$ & 3.6 & 3.6 & 4.5 & 4.6 & 0.10 & $* *$ & ns & ns \\
\hline $\mathrm{g} / \mathrm{kg} \mathrm{BW}^{0.75}$ & 59.6 & 59.5 & 72.4 & 75.3 & 2.34 & $*$ & ns & ns \\
\hline \multicolumn{9}{|l|}{ Concentrate } \\
\hline $\mathrm{kg} / \mathrm{d}$ & 1.2 & 1.3 & 1.2 & 1.2 & 0.04 & ns & ns & ns \\
\hline $\mathrm{g} / \mathrm{kg} \mathrm{BW}^{0.75}$ & 19.5 & 20.4 & 19.6 & 19.3 & 0.15 & ns & ns & ns \\
\hline \multicolumn{9}{|l|}{ Total } \\
\hline $\mathrm{kg} / \mathrm{d}$ & 4.7 & 4.9 & 5.7 & 5.7 & 0.11 & $*$ & ns & ns \\
\hline $\mathrm{g} / \mathrm{kg} \mathrm{BW}^{0.75}$ & 79.1 & 80.0 & 92.0 & 94.6 & 2.47 & $*$ & ns & ns \\
\hline \multicolumn{9}{|l|}{ Nutrients intake $(\mathrm{kg})$} \\
\hline Organic matter & 3.9 & 4.2 & 5.0 & 5.1 & 0.07 & $* *$ & ns & ns \\
\hline Crude protein & 0.3 & 0.3 & 0.4 & 0.4 & 0.01 & $* *$ & ns & ns \\
\hline Neutral detergent fiber & 3.0 & 3.2 & 3.9 & 4.0 & 0.05 & $* *$ & ns & ns \\
\hline Acid detergent fiber & 2.6 & 2.8 & 3.4 & 3.5 & 0.07 & $* *$ & ns & ns \\
\hline \multicolumn{9}{|l|}{ Apparent digestibility (\%) } \\
\hline Dry matter & 56.7 & 56.5 & 62.4 & 63.1 & 1.28 & $*$ & ns & ns \\
\hline Organic matter & 61.7 & 61.5 & 67.3 & 67.6 & 1.13 & $*$ & ns & ns \\
\hline Crude protein & 50.9 & 50.6 & 67.9 & 68.4 & 1.42 & $* *$ & ns & ns \\
\hline Neutral detergent fiber & 55.8 & 60.0 & 65.7 & 64.7 & 1.02 & $*$ & ns & ns \\
\hline Acid detergent fiber & 51.3 & 55.6 & 60.2 & 60.0 & 1.26 & $*$ & ns & ns \\
\hline
\end{tabular}

${ }^{1} \mathrm{U}=$ Untreated rice straw vs urea-treated (3\%) rice straw, $\mathrm{P}=$ Long form rice straw vs chopped $(4 \mathrm{~cm})$ rice straw, $\mathrm{U} \times \mathrm{P}$ roughage source and physical form interaction. $* \mathrm{p}<0.05, * * \mathrm{p}<0.01, \mathrm{~ns}=$ Non-significant $(\mathrm{p}>0.05)$. 
Table 3. Effect of physical form and urea treatment of rice straw on rumen fermentation and BUN in dairy steers

\begin{tabular}{|c|c|c|c|c|c|c|c|c|}
\hline \multirow{2}{*}{ Item } & \multicolumn{2}{|c|}{$\mathrm{RS}$} & \multicolumn{2}{|c|}{ UTRS } & \multirow{2}{*}{ SEM } & \multicolumn{3}{|c|}{ Significance $^{1}$} \\
\hline & LFR & CHR & LFR & CHR & & $\mathrm{U}$ & $\mathrm{P}$ & $\mathrm{U} \times \mathrm{P}$ \\
\hline$\overline{\mathrm{pH}}$ & 6.3 & 6.6 & 6.4 & 6.2 & 0.02 & * & ns & $*$ \\
\hline $\mathrm{NH}_{3}-\mathrm{N}(\mathrm{mg} / \mathrm{dL})$ & 14.1 & 12.4 & 19.6 & 22.8 & 1.50 & $* *$ & ns & ns \\
\hline BUN (mg/dL) & 3.2 & 4.6 & 12.5 & 12.4 & 0.57 & $* *$ & ns & ns \\
\hline Total VFA (mM) & 113.1 & 107.4 & 122.8 & 127.1 & 2.15 & $*$ & ns & ns \\
\hline \multicolumn{9}{|l|}{ VFA, mol/100 mol } \\
\hline Acetic acid (C2) & 71.3 & 69.8 & 70.0 & 70.5 & 0.47 & ns & ns & ns \\
\hline Propionic acid (C3) & 20.1 & 20.3 & 21.5 & 21.4 & 0.15 & $*$ & ns & ns \\
\hline Butyric acid (C4) & 8.5 & 10.0 & 8.4 & 8.2 & 0.73 & ns & ns & ns \\
\hline $\mathrm{C} 2: \mathrm{C} 3$ & 3.7 & 3.5 & 3.3 & 3.4 & 0.15 & $\mathrm{~ns}$ & $\mathrm{~ns}$ & ns \\
\hline
\end{tabular}

${ }^{1} \mathrm{U}=$ Untreated rice straw vs urea-treated (3\%) rice straw, $\mathrm{P}=$ Long form rice straw vs chopped $(4 \mathrm{~cm})$ rice straw, $\mathrm{U} \times \mathrm{P}$ roughage source and physical form interaction. $* \mathrm{p}<0.05, * * \mathrm{p}<0.01, \mathrm{~ns}=$ Non-significant $(\mathrm{p}>0.05)$.

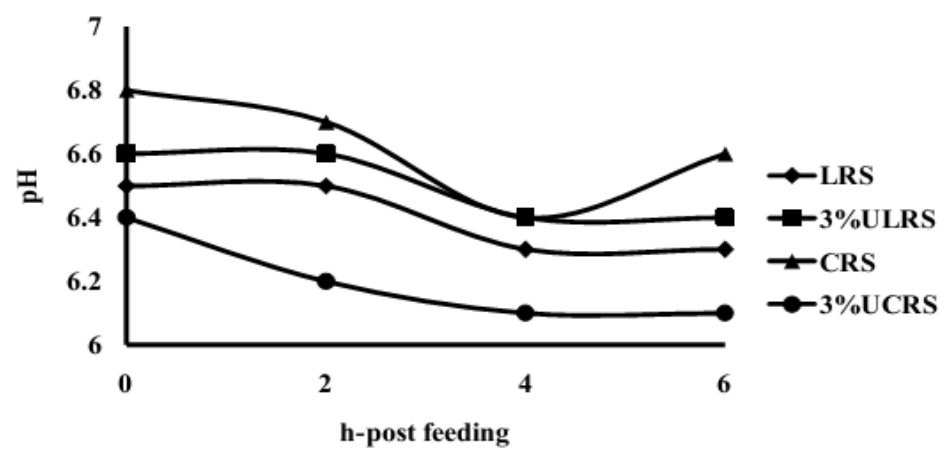

Figure 1. Effect of physical form and urea treatment of rice straw on ruminal $\mathrm{pH}$ at $0,2,4$, and 6 h-post feeding in dairy steers.

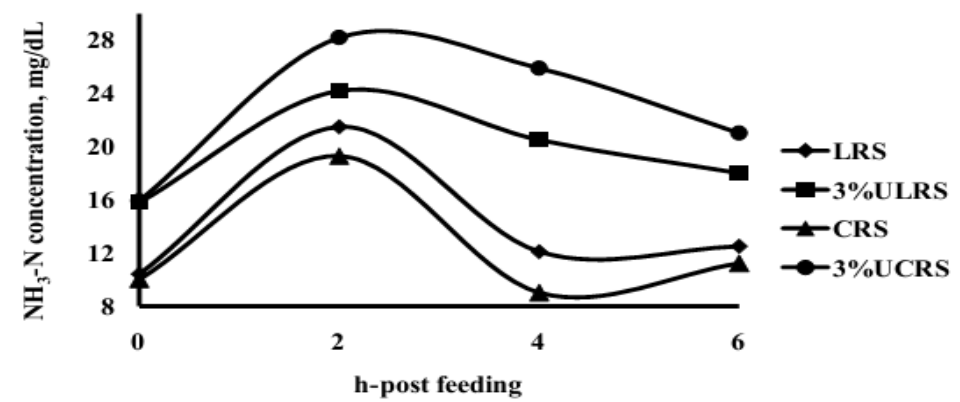

Figure 2. Effect of physical form and urea treatment of rice straw on rumen $\mathrm{NH}_{3}-\mathrm{N}$ concentration at $0,2,4$, and 6 h-post feeding in dairy steers.

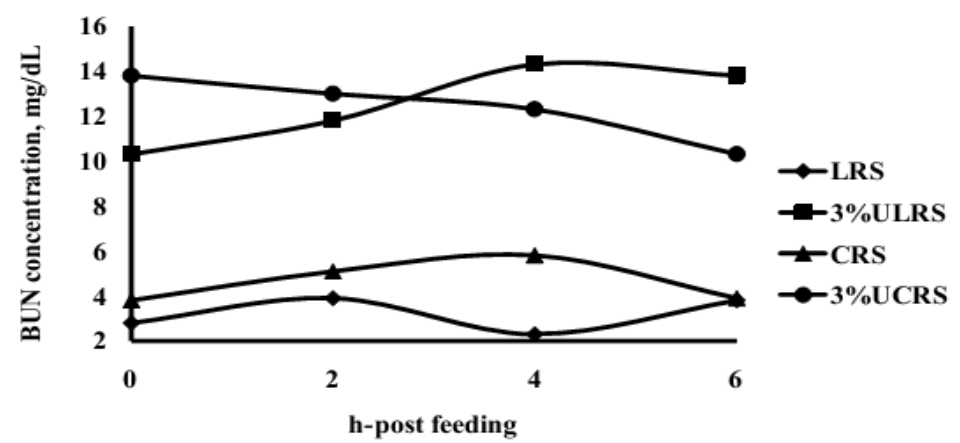

Figure 3. Effect of physical form and urea treatment of rice straw on BUN concentration at $0,2,4$, and 6 h-post feeding in dairy steers. 


\section{N balance and efficiency of MCP synthesis}

The effects of physical form and urea treatment of rice straw on $\mathrm{N}$ balance, urinary PD excretion and MCP synthesis in dairy steers are reported in Table 4. Differences between roughage sources were found for $\mathrm{N}$ utilization. $\mathrm{N}$ intake, excretion (fecal and urinary) and balance (absorption and retention) were increased $(\mathrm{p}<0.05)$ for UTRS compared with RS. There was no affect of the physical form of rice straw on $\mathrm{N}$ utilization ( $\mathrm{p}>0.05)$. Allantoin excretion, absorption and microbial CP synthesis were higher $(\mathrm{p}<0.05)$ for UTRS and CHR group. In addition, EMNS was greater $(\mathrm{p}<0.05)$ for UTRS than for RS.

\section{DISCUSSION}

Steers fed UTRS had a higher total intake than those fed RS (from 3.6 to $4.6 \mathrm{~kg}$ ). Similarly, Wanapat et al. (2009) reported that $5.5 \%$ UTRS increased DM intake in dairy cows (from 4.4 to $6.0 \mathrm{~kg}$ ) when compared with RS. However, decreasing particle size of rice straw for dairy steers had no effect on DM intake. This result is consistent with some previous studies (Yang et al., 2002; Yang and Beauchemin, 2005; Yang and Beauchemin, 2006a; Zhao et al., 2009), but others have observed DM intake increased by reducing particle size of diets (Kononoff and Heinrichs, 2003; Kononoff et al., 2003; Krause and Combs, 2003). Beauchemin et al. (1997) found that when poor quality, high fiber diets were fed, reducing the roughage particle size significantly increased DM intake. In the present study, using poor quality roughage (rice straw) particle size did not influence rice straw intake and total DM intake. Tafaj et al. (2007) reported that the effect of dietary particle size on DM intake may depend on roughage sources, type of concentrates, especially its ruminal degradation rate, reflecting their effects on rumen conditions and digestion. In addition, increased availability of nutrients due to the urea treatment of rice straw, could promote the observed higher total DM intake in dairy steers. Nutrient intake in terms of OM, CP, NDF, and ADF was increased by urea treatment and the combined effect of the higher total DM intake. These results were similar to previous work of Abate and Melaku (2009) and Hossain et al. (2010) who reported that urea-treated rice straw or barley straw had increased OM, CP, NDF, and ADF intake. Other factors, such as physical properties and palatability of feed, also affect intake (Huyen et al., 2012). Under this study, urea-treated rice straw supplied more moisture $(51.0 \%$ DM) than untreated rice straw $(93.7 \% \mathrm{DM})$, indicating that urea treated straw was highly palatable. The increase in palatability might be due to the blending and processing of less palatable fibrous straw (Jaglan and Kishore, 2005), which may partially explain our observed increase in DM and nutrient intake.

The apparent digestibility of DM, OM and CP was greater in steers receiving UTRS than RS. These results were in agreement with Wanapat et al. (2009) who reported that 5.5\% UTRS could improve digestibility of DM, OM, and CP. In the present study, digestibility of CP increased, which may have been due to the higher $\mathrm{CP}$ content in the UTRS and enhanced CP intake. Moreover, NDF and ADF digestibility was higher for UTRS than for RS. Hart and Wanapat (1992) reported that UTRS could increase digestibility of NDF and ADF. Ammonium hydroxide $\left(\mathrm{NH}_{4} \mathrm{OH}\right)$ formed in UTRS produces a swelling of the hemicelluloses-lignin complex in rice straw (Mapato et al., 2010). Resulting in an increased surface area available for attack by rumen microorganisms and thus increasing the rate of breakdown and the rate of passage of treated straw

Table 4. Effect of physical form and urea treatment of rice straw on $\mathrm{N}$ balance, urinary purine derivatives and MCP synthesis in dairy steers

\begin{tabular}{|c|c|c|c|c|c|c|c|c|}
\hline \multirow{2}{*}{ Item } & \multicolumn{2}{|c|}{$\mathrm{RS}$} & \multicolumn{2}{|c|}{ UTRS } & \multirow{2}{*}{ SEM } & \multicolumn{3}{|c|}{ Significance $^{1}$} \\
\hline & LFR & CHR & LFR & CHR & & $\mathrm{U}$ & $\mathrm{P}$ & $\mathrm{U} \times \mathrm{P}$ \\
\hline \multicolumn{9}{|l|}{$\mathrm{N}$ utilization $(\mathrm{g} / \mathrm{d})$} \\
\hline $\mathrm{N}$ intake & 43.9 & 43.8 & 71.5 & 73.1 & 1.31 & $* *$ & ns & ns \\
\hline \multicolumn{9}{|l|}{ N excretion } \\
\hline Fecal & 27.4 & 30.1 & 36.4 & 40.0 & 1.24 & * & ns & ns \\
\hline Urinary & 7.6 & 5.5 & 21.1 & 19.0 & 1.02 & $* *$ & ns & ns \\
\hline \multicolumn{9}{|l|}{$\mathrm{N}$ balance } \\
\hline Absorption & 16.5 & 13.7 & 35.2 & 33.2 & 0.69 & $* *$ & ns & ns \\
\hline Retention & 8.9 & 11.0 & 14.1 & 14.2 & 0.84 & $*$ & ns & ns \\
\hline \multicolumn{9}{|c|}{ Urinary purine derivatives $(\mathrm{mmol} / \mathrm{d})$} \\
\hline Allantoin excretion & 63.2 & 73.2 & 76.9 & 85.3 & 2.22 & $*$ & $*$ & ns \\
\hline Allantoin absorption & 76.1 & 85.6 & 88.3 & 95.4 & 1.84 & $*$ & $*$ & ns \\
\hline $\operatorname{MCP}(\mathrm{g} / \mathrm{d})$ & 345.9 & 389.2 & 401.2 & 433.7 & 8.37 & $*$ & $*$ & ns \\
\hline EMNS $\left(\mathrm{g} / \mathrm{kg} \mathrm{OMDR}^{\mathrm{g}}\right)$ & 18.9 & 18.4 & 21.9 & 21.6 & 0.30 & $*$ & ns & ns \\
\hline
\end{tabular}

${ }^{1} \mathrm{U}=$ Untreated rice straw vs urea-treated (3\%) rice straw, $\mathrm{P}=$ long form rice straw vs chopped (4 cm) rice straw, $\mathrm{U} \times \mathrm{P}$ roughage source and physical form interaction. $* \mathrm{p}<0.05, * * \mathrm{p}<0.01, \mathrm{~ns}=$ Non-significant $(\mathrm{p}>0.05)$. 
through the digestive tract (Goto and Yokoe, 1996; Ha et al., 2001). These effects may explain the action of urea treatment in improving rumen microbial degradation of rice straw by making the cellulose and hemicellulose more accessible for the rumen microbes (Shen et al., 1999). Digestion of NDF and ADF was increased from $58 \%$ to $65 \%$ and from $54 \%$ to $60 \%$, respectively, when steers were fed UTRS. In addition, a different physical form of rice straw did not influence nutrient digestibility. These results are consistent with several reports (Yang and Beauchemin, 2005; Yang and Beauchemin, 2006b), but in contrast to other findings (Yang et al., 2002; Zhao et al., 2009).

Ruminal $\mathrm{pH}$ was lower (6.2) for UTRS+CHR than for the UTRS+LFR and RS groups. One of the most important factors influencing rumen $\mathrm{pH}$ is the amount of saliva buffer secretion, which is positively correlated with rumination activity (Lu et al., 2005). These results were in agreement with Zhao et al. (2009) reported that the reduction in the particle size of rice straw reduced ruminal $\mathrm{pH}$. Moreover, Van Soest (1994) reported that cellulolytic organisms grow optimally at pH 6.7 and $\mathrm{pH}$ below 6.2 inhibited the rate of digestion, decreased acetic acid and depressed cellulolytic activity. In the present study, ruminal $\mathrm{pH}$ in the range 6.2 to 6.6 was optimized for cellulolytic bacteria and fiber digestion in the rumen. Moreover, ruminal $\mathrm{NH}_{3}-\mathrm{N}$ and BUN concentrations were increased when steers were fed UTRS. This result was consistent with previous studies which indicated that UTRS had affected ruminal $\mathrm{NH}_{3}-\mathrm{N}$ concentration (Wanapat, 2000; Wanapat et al., 2009; Maputo et al., 2010). Higher ruminal $\mathrm{NH}_{3}-\mathrm{N}$ concentration occurred when steers were fed UTRS because of the relatively high levels of soluble CP for UTRS than for RS ( $5.4 \%$ vs $2.5 \% \mathrm{CP})$, which would likely have caused higher rumen ammonia levels, particularly immediately after feeding (Highstreet et al., 2010). However, $\mathrm{NH}_{3}-\mathrm{N}$ concentration was not affected by chopping of rice straw. Similarly, Onetti et al. (2003) reported that reducing the particle size of corn silage did not affect the rumen $\mathrm{NH}_{3}-\mathrm{N}$ concentration. This result agreed with the study of Beauchemin and Yang (2005), suggesting that reduction of forage particle size may not have affected the protein digestion in the rumen. Moreover, concentrations of BUN were highly correlated to the level of $\mathrm{NH}_{3}$ production in the rumen (Preston et al., 1965). Ruminal $\mathrm{NH}_{3}-\mathrm{N}$ concentrations were 12.4 to $22.8 \mathrm{mg} / \mathrm{deal}$ and were closer to the optimal ruminal NH3-N range (15 to $30 \mathrm{mg} / \mathrm{dL}$, Perdok and Leng, 1990; Wanapat et al., 2008; Poungchompu et al., 2009; Anantasook et al., 2013).

The production of acetic acid, butyric acid and acetic: propionic ratio was similar among all treatments. However, the concentration of total VFA and propionic acid was increased when steers were fed UTRS. These results were in agreement with Wanapat et al. (2009) who reported that propionic acid was higher for 5.5\% UTRS than for RS in dairy cows. Opera et al. (1975) also reported that $\mathrm{N}$ supplementation from urea could increase the activity of rumen microbes in degrading carbohydrates (cellulose and starch) for VFA production when the energy level was sufficient. Under this study, total VFA concentrations in all treatments ranged from 108.3 to $124.9 \mathrm{~mm}$ and were found at normal concentrations (70 to $130 \mathrm{~mm}$, Wanapat and Pimpa, 1999; Wanapat et al., 2013). Chopping of rice straw did not affect VFA production. These results are similar with those of Yuangklang et al. (2010) who reported that VFA production was observed to be unaffected by decreased rice straw particle size in beef cattle. Zhao et al. (2009) reported that total VFA, acetate: propionate ratio and individual VFA remained similar across the decreased particle sizes of rice straw in goats.

Total $\mathrm{N}$ intake and $\mathrm{N}$ excretion (fecal and urinary) were all higher for UTRS than for RS. Urinary excretion of $\mathrm{N}$ will arise when there is ammonia accumulation in the rumen or high levels of deamination occurring in the body, due to excess protein fed or an unbalanced amino acid profile (Galo et al., 2003). In contrast with these results, Sinha et al. (2011) did not find an effect on total N intake, fecal and urinary $\mathrm{N}$ excretion in Mithun (Bos frontalis) fed on urea-treated paddy straw when compared to Napier grass. In addition, $\mathrm{N}$ absorption and $\mathrm{N}$ retention were found to be greater in steers fed urea-treated rice straw. The $\mathrm{N}$ retention was positive in all diets, ranging from 8.9 to $14.2 \mathrm{~g} / \mathrm{d}$. This result agreed with Pradhan et al. (1996) who reported that the $\mathrm{N}$ retention was increased by urea or ammonia treated rice straw when compared with untreated rice straw. Urea treatment of rice straw increased $\mathrm{N}$ intake as well as its absorption and retention indicating that this treatment could improve the performance of the steers. While, chopping of rice straw did not influence $\mathrm{N}$ utilization. These results were in agreement with previous reports, which indicated $\mathrm{N}$ intake, excretion and retention were not affected by the different particle sizes of rice straw (Wang et al., 2011).

The PD excreted in the urine originated from absorbing microbial purines and purines from the animal tissues (Chen et al., 1992). The urinary Allentown excretion, absorption and MCP synthesis were increased in the UTRS and CHR fed groups. The EMNS based on organic matter truly digested in the rumen were enhanced by UTRS. Hoover and Stokes (1991) reported that the rate of digestion of carbohydrates was a major factor controlling the energy available for microbial growth. Under this present study, concentrate was fed at the level of $0.5 \% \mathrm{BW} / \mathrm{d}$ with urea treatment and chopped rice straw was used as a roughage source, both of which could synchronize to produce ruminal $\mathrm{NH}_{3}-\mathrm{N}$ and $\mathrm{C}$-skeletons, suitable for ruminal MCP synthesis. Hence, $\mathrm{NH}_{3}-\mathrm{N}$ concentration was increased from 13.3 to $21.2 \mathrm{mg} / \mathrm{dL}$ and enhanced efficiency of MCP synthesis in 
the rumen. However, EMNS was not influenced by CHR alone. Similarly, Wang et al. (2011) reported that different particle size of rice straw did not affect EMNS. The MCP synthesis from the rumen as calculated from purine derivative excretion using the equation of Chen and Gomes (1995) ranged from 345.9 to $433.7 \mathrm{~g} / \mathrm{d}$. These values were relatively high in supporting the productivity of ruminants.

\section{CONCLUSIONS}

In conclusion, feeding of urea-treated $(3 \%)$ rice straw to dairy steers resulted in an improved DM intake, nutrient digestibility, rumen fermentation especially $\mathrm{NH}_{3}-\mathrm{N}$, propionic acid, $\mathrm{N}$ utilization, MCP synthesis and EMNS. However, no effect of chopping rice straw was found, except for MCP synthesis. Therefore, long form rice straw treated with urea improved nutrient digestibility, rumen fermentation and EMNS in crossbred dairy steers.

\section{ACKNOWLEDGEMENTS}

The authors would like to express their most sincere gratitude and appreciation to the Tropical Feed Resources Research and Development Center (TROFREC) and Graduate School of Khon Kaen University for providing financial support for the research and for the use of the research facilities.

\section{REFERENCES}

Abate, D. and S. Melaku. 2009. Effect of supplementing ureatreated barley straw with lucerne or vetch hays on feed intake, digestibility and growth of Arsi Bale sheep. Trop. Anim. Health Prod. 41:579-586.

Anantasook, N., M. Wanapat, A. Cherdthong, and P. Gunun. 2013. Effect of plants containing secondary compounds with palm oil on feed intake, digestibility, microbial protein synthesis and microbial population in dairy cows. Asian Australas. J. Anim. Sci. 26:820-826.

AOAC. 1995. Official method of analysis. 16th ed. Animal Feeds: Association of Official Analytical Chemists, VA, USA.

Beauchemin, K. A. and W. Z. Yang. 2005. Effects of physically effective fiber on intake, chewing activity, and ruminal acidosis for dairy cows fed diets based on corn silage. J. Dairy Sci. 88:2117-2129.

Beauchemin, K. A., L. M. Rode, and W. Z. Yang. 1997. Effects of nonstructural carbohydrates and source of cereal grain in high concentrate diets of dairy cows. J. Dairy Sci. 80:1640-1650.

Chemjon, P. B. 1991. Economic value of urea-treated straw fed to lactating buffaloes during the dry season in Nepal. Trop. Anim. Health Prod. 23:147-154.

Chen, X. B. and M. J. Gomes. 1995. Estimation of microbial protein supply to sheep and cattle based on urinary excretion of purine derivative-an overview of the technique details. Occasional Publication 1992. International Feed Resources Unit, Rowett Research Institute, Aberdeen, UK.
Chen, X. B., Y. K. Chen, M. F. Franklin, E. R. Ørskov, and W. J. Shand. 1992. The effect of feed intake and body weight on purine derivative excretion and microbial protein supply in sheep. J. Anim. Sci. 70:1534-1542.

Crocker, C. L. 1967. Rapid determination of urea nitrogen in serum or plasma without deproteinization. Am. J. Med. Technol. 33:361-365.

Galo, E., S. M. Emanuele, C. J. Sniffen, J. H. White, and J. R. Knapp. 2003. Effects of a polymer-coated urea product on nitrogen metabolism in lactating Holstein dairy cattle. J. Dairy Sci. 86:2154-2162.

Goto, M. and Y. Yokoe. 1996. Ammoniation of barley straw. Effect on cellulose crystallinity and water-holding capacity. Anim. Feed Sci. Technol. 58:239-247.

Ha, J. K., S. S. Lee, S. W. Kim, In K. Han, K. Ushida, and K. -J. Cheng. 2001. Degradation of rice straw by rumen fungi and cellulolytic bacteria through mono-, co- or sequential- cultures. Asian-Aust. J. Anim. Sci. 14:797-802.

Hanafi, E. M., H. H. El Khadrawy, W. M. Ahmed, and M. M. Zaabal. 2012. Some observation on rice straw with emphasis on updates of its management. World Appl. Sci. J. 16:354-361.

Hart, F. J. and M. Wanapat. 1992. Physiology of digestion of ureatreated rice straw in swamp buffaloes. Asian-Aus. J. Anim. Sci. 5:617-622.

Highstreet, A., P. H. Robinson, J. Robison, and J. G. Garrett. 2010. Response of Holstein cows to replacing urea with a slowly rumen released urea in a diet high in soluble crude protein. Livest. Sci. 129:179-185.

Hoover, W. H. and S. R. Stokes. 1991. Balancing carbohydrates and proteins for optimum rumen microbial yield. J. Dairy Sci. 74:3630-3644.

Hossain, M. M., M. J. Khan, and M. A. Akbar. 2010. Nutrient digestibility and growth of local bull calves as affected by feeding urea and urease enzyme sources treated rice straw. Bang. J. Anim. Sci. 39:97-105.

Huyen, N. T., M. Wanapat, and C. Navanukraw. 2012. Effect of mulberry leaf pellet (MUP) supplementation on rumen fermentation and nutrient digestibility in beef cattle fed on rice straw-based diets. Anim. Feed Sci. Technol. 175:8-15.

Jaglan, B. S. and N. Kishore. 2005. Compaction behavior of urea treated crop residues in feed blocks. Indian J. Anim. Nutr. 22:90-93.

Khandaker, Z. H., M. M. Uddin, M. N. Sultana, and K. J. Peters. 2012. Effect of supplementation of mustard oil cake on intake, digestibility and microbial protein synthesis of cattle in a straw-based diet in Bangladesh. Trop. Anim. Health Prod. 44: 791-800.

Khejornsart, P. and M. Wanapat. 2010. Effect of chemical treatment of rice straw on rumen fermentation characteristic, anaerobic fungal diversity in vitro. J. Anim. Vet. Adv. 9:30703076.

Kononoff, P. J. and A. J. Heinrichs. 2003. The effect of reducing alfalfa haylage particle size on cows in early lactation. J. Dairy Sci. 86:1445-1457.

Kononoff, P. J., A. J. Heinrichs, and D. R. Buckmaster. 2003. Modification of the Penn state forage and total mixed ration particle separator and the effects of moisture content on its measurements. J. Dairy Sci. 86:1858-1863.

Krause, K. M. and D. K. Combs. 2003. Effects of forage particle 
size, forage source, and grain fermentability on performance and ruminal $\mathrm{pH}$ in midlactation cows. J. Dairy Sci. 86:13821397.

Lu, C. D., J. R. Kawas, and O. G. Mahgoub. 2005. Fibre digestion and utilization in goats. Small Rumin. Res. 60:45-52.

Mapato, C., M. Wanapat, and A. Cherdthong. 2010. Effect of urea treatment of straw and dietary level of vegetable oil on lactating dairy cows. Trop. Anim. Health Prod. 42:1635-1642.

Maulfair, D. D., M. Fustini, and A. J. Heinrichs. 2010. Effect of varying total mixed ration particle size on rumen digesta and fecal particle size and digestibility in lactating dairy cows. J. Dairy Sci. 94:3527-3536.

McDonald, A. A., R. A. Edwards, J. F. D. Greenhalgh, and C. A. Morgan. 2002. Animal Nutrition. 6th ed. Harlow: Pearson Education.

Nguyen, V. N., M. Wanapat, P. Khejornsart, and P. Kongmun. 2012. Nutrient digestibility and ruminal fermentation characteristic in swamp buffaloes fed on chemically treated rice straw and urea. Trop. Anim. Health Prod. 44:629-636.

Obara, Y., K. Shimbayashi, and T. Yonemura. 1975. Change of ruminal properties of sheep during feeding urea diet. Jpn. J. Zootech. Sci. 46:140-145.

Onetti, S. G., R. D. Shaver, S. J. Bertics, and R. R. Grummer. 2003. Influence of corn silage particle length on the performance of lactating dairy cows fed supplemental tallow. J. Dairy Sci. 86:2949-2957.

Perdok, H. B. and R. A. Leng. 1990. Effect of supplementation protein meal on the growth of cattle given a basal diet of untreated or ammoniated rice straw. Asian-Aus. J. Anim. Sci. 3:269-279.

Poungchompu, O., M. Wanapat, C. Wachirapakorn, S. Wanapat, and A. Cherdthong. 2009. Manipulation of ruminal fermentation and methane production by dietary saponins and tannins from mangosteen peel and soapberry fruit. Arch. Anim. Nutr. 63:389-400.

Pradhan, R., H. Tobioka, and I. Tasaki. 1996. Effect of urea and ammonia treatment on voluntary intake, digestibility, energy partition and nitrogen retention of rice straw supplemented with soybean meal and fish meal in goats. Anim. Sci. Technol. 67:702-712.

Preston, R. L., D. D. Schnakanberg, and W. H. Pander. 1965. Protein utilization in ruminants. I. Blood urea nitrogen as affected by protein intake. J. Nutr. 86:281-288.

Safari, J. G., D. E. Mushi, L. A. Mtenga, G. C. Kifaro, and L. O. Eik. 2011. Growth, carcass yield and meat quality attributes of Red Maasai sheep fed wheat straw-based diets. Trop. Anim. Health Prod. 43:89-97.

Samuel, M., S. Sagathewan, J. Thomus, and G. Mathen. 1997. An HPLC method for estimation of volatile fatty acids of rumen fluid. Indian J. Anim. Sci. 67:805-807.

SAS. 1996. User's Guide: Statistic, Version 5. Edition. SAS. Inst Cary, NC, USA.

Shen, H. S., F. Sundstøl, E. R. Eng, and L. O. Eik. 1999. Studies on untreated and urea-treated rice straw from three cultivation seasons: 3. Histological investigations by light and scanning electron microscopy. Anim. Feed Sci. Technol. 80:151-159.

Sinha, D., B. Prakash, B. N. Neog, K. K. Baruah, S. Sarmah, and C. Rajkhowa. 2011. Intake, digestibility and nitrogen balance in Mithun (Bos frontalis) offered urea-treated paddy straw based feed blocks. Trop. Anim. Health Prod. 43:383-387.

Su, Y., G. Zhao, Z. Wei, C. Yan, and S. Liu. 2012. Mutation of cellulose synthase gene improves the nutritive value of rice straw. Asian-Aust. J. Anim. Sci. 25:800-805.

Sundstøl, F., E. Coxworth, and D. N. Mowat. 1978. Improving the nutritive value of wheat straw and other low quality roughages by treatment with ammonia. World Anim. Rev. 26:13-21.

Tafaj, M., Q. Zebeli, Ch. Baes, H. Steingass, and W. Drochner. 2007. A meta-analysis examining effects of particle size of total mixed rations on intake, rumen digestion and milk production in high-yielding dairy cows in early lactation. Anim. Feed Sci. Technol. 138:137-161.

Van Soest, P. J., J. B. Robertson, and B. A. Lewis. 1991. Methods for dietary fiber neutral detergent fiber, and non starch polysaccharides in relation to animal nutrition. J. Dairy Sci. 74:3583-3597.

Van Soest, P. J. 1994. Nutritional ecology of the ruminant. Cornell University Press, New York, NY.

Wanapat, M. 2000. Rumen manipulation to increase the efficient use of local feed resources and productivity of ruminants in the tropics. Asian-Aust. J. Anim. Sci. 13(Suppl.):59-67.

Wanapat, M. and O. Pimpa. 1999. Effect of ruminal $\mathrm{NH}_{3}-\mathrm{N}$ levels on ruminal fermentation, purine derivatives, digestibility and rice straw intake in swamp buffaloes. Asian-Aust. J. Anim. Sci. 12:904-907.

Wanapat, M., F. Sundstøl, and T. H. Garmo. 1985. A comparison of alkali treatment methods to improve the nutritive value of straw. I. Digestibility and metabolizability. Anim. Feed Sci. Technol. 12:295-309.

Wanapat, M., A. Cherdthong, P. Pakdee, and S. Wanapat. 2008. Manipulation of rumen ecology by dietary lemongrass (Cymbopogon citrates Stapf.) powder supplementation. J. Anim. Sci. 86:3497-3503.

Wanapat, M., S. Polyorach, K. Boonnop, C. Mapato, and A. Cherdthong. 2009. Effects of treating rice straw with urea or urea and calcium hydroxide upon intake, digestibility, rumen fermentation and milk yield of dairy cows. Livest. Sci. 125:238-243

Wanapat, M., R. Pilajun, S. Kang, K. Setyaningsih, and A. R. Setyawan. 2012. Effect of ground corn cob replacement for cassava chip on feed intake, rumen fermentation and urinary derivatives in swamp buffaloes. Asian-Aust. J. Anim. Sci. 25:1124-1131.

Wanapat, M., N. Anantasook, P. Rowlinson, R. Pilajun, and P. Gunun. 2013. Effect of carbohydrate sources and levels of cotton seed meal in concentrate on feed intake, nutrient digestibility, rumen fermentation and microbial protein synthesis in young dairy bulls. Asian-Aust. J. Anim. Sci. 26:529-536.

Wang, M., X. G. Zhao, H. Y. Liao, Z. L. Tan, S. X. Tang, Z. H. Sun, C. S. Zhou, and X. F. Han. 2011. Effects of rice straw particle size on digesta particle size distribution, nitrogen metabolism, blood biochemical parameters, microbial amino acid composition and intestinal amino acid digestibility in goats. Anim. Sci. J. 82:78-85.

Yang, W. Z. and K. A. Beauchemin. 2005. Effects of physically effective fiber on digestion and milk production by dairy cows fed diets based on corn silage. J. Dairy Sci. 88:1090-1098.

Yang, W. Z. and K. A. Beauchemin. 2006a. Effects of physically 
effective fiber on chewing activity and ruminal $\mathrm{pH}$ of dairy cows fed diets based on barley silage. J. Dairy Sci. 89:217-228.

Yang, W. Z. and K. A. Beauchemin. 2006b. Physically effective fiber: method of determination and effects on chewing, ruminal acidosis, and digestion by dairy cows. J. Dairy Sci. 89:2618-2633.

Yang, W. Z. and K. A. Beauchemin. 2009. Increasing physically effective fiber content of dairy cow diets through forage proportion versus forage chop length: chewing and ruminal $\mathrm{pH}$. J. Dairy Sci. 92:1603-1615.
Yang, W. Z., K. A. Beauchemin, and L. M. Rode. 2002. Effects of particle size of alfalfa-based dairy cow diets on site and extent of digestion. J. Dairy Sci. 85:1958-1968.

Yuangklang, C., C. Wongnen, C. Patiphan, J. Khotsakdee, T. Kandee, K. Vasupen, S. Bureenok, S. Wongsuthavas, A. Alhaidary, H. E. Mohamed, and A. C. Beynen. 2010. Rumen fermentation in beef and buffalo steers fed native or treated rice straw. J. Anim. Vet. Adv. 9:3011-3015.

Zhao, X. G., M. Wang, Z. L. Tan, S. X. Tang, Z. H. Sun, C. S. Zhou, and X. F. Han. 2009. Effects of rice straw particle size on chewing activity, feed intake, rumen fermentation and digestion in goats. Asian-Aust. J. Anim. Sci. 22:1256-1266. 